DOI: $10.20472 / B M .2015 .3 .3 .002$

\title{
COMPLAINT MANAGEMENT ON THE POLISH FINANCIAL MARKET - THE DIMENSIONS OF CUSTOMER EVALUATION
}

\section{MALWINA BERGER}

\begin{abstract}
:
Justice theory appears to be dominant theoretical framework applied to complaint handling. A three-dimensional view of the concept of justice has evolved over time to include distributive justice (dealing with decision outcomes), procedural justice (dealing with decision-making procedures), and interactional justice (dealing with interpersonal behavior in the enactment of procedures and delivery of outcomes). However, a few recent studies analyze the impact of perceived justice which include informational justice (adequacy and truthfulness of information delivered to a customer) as an independent variable. Also, a lack of consistency, among some of the categories falling within particular justice, can be observed. Perceived justice concept has not been tested yet with regard to concentrated service sectors and business reality of post-communist European countries. As a result this paper aims at verifying the extent to which perceived justice is multidimensional from a perspective of financial institutes' clients in Poland. The research was conducted on the sample of 400 customers. There is a support to use a four-dimension model. There were some new constructs found, which enrich measures of justice, e.g.: providing the client with the possibility of choosing compensation, a single-person complaint handling, the competence of the personnel. The results are interpreted in relation to other research related to this issue and prior own qualitative study.
\end{abstract}

\section{Keywords:}

Complaint, justice theory, multidimensionality of complaint management, financial market, Poland

\section{Authors:}

MALWINA BERGER, University of Economics in Katowice, Poland, Email:

malwina.berger@ue.katowice.pl

\section{Citation:}

MALWINA BERGER (2015). Complaint management on the polish financial market - the dimensions of customer evaluation. International Journal of Business and Management, Vol. III(3), pp. 12-21., 10.20472/BM.2015.3.3.002 


\section{Introduction}

Prior studies have shown that the conflict, which often manifests itself by the fact of rising a complaint, affects customers' positive and negative behavioral intentions. Among the destructive outcomes of conflict the following would deserve being mentioned: the termination of the relationship with a company or spreading negative opinions about the company (e.g Blodgett, Hill, Tax, 1997; Ward, Ostrom, 2006). The effective coordination of the course of conflict may, in turn, result in the increase of overall satisfaction and positive feedback (e.g. Maxham, Netemeyer, 2002; Maxham, 2003; Homburg, Fürst, 2005). Considering the above, it seems important to identify the factors determining the effective conflict resolution in the buyer-seller relationship.

Complaint management research has mostly been done in highly developed countries (i.e. in the USA, Canada, Great Britain, Norway, and Israel), despite the fact that those methods have also been applied to average developed and underdeveloped countries ( e.g. Brasil, China, India) only in one research were those methods used in a postcommunist, European country, that is in Croatia, nevertheless it needs to be stressed that the research has been performed only on a small group of students (Nefat, Benazic, Aleric 2012). In general European, post-communist countries provide an interesting field for research on costumer conflict management, inter alia, due to the fact that they have a rather small level of social capital, which is helpful in resolving conflicts. For instance in strategic legal documents Poland is treated as an unique, in the context of Europe, "desert of social capital" (Wygnański, Herbst 2010).

Furthermore, previous studies on the negative aspects of the relationship were related to different sectoral ${ }^{1}$ and cultural contexts, which means that they did not include the specificity of Polish reality of running a business such as: the influence of the so called real socialism on the customer service culture, as well as the impact of specific Polish national culture. Meanwhile Orshinger, Valentini and De Angelis (2010) maintain that cultural differences should be taken into account, since the results of research on factors determining the results of complaint situation depend on these differences, e.g. in high individualistic cultures (e.g. USA) specific behavior of the contact personnel plays a crucial role.

Studies concerning the justice of complaint management have been mostly carried out on food and tourist markets, which are known for a relatively high levels of competition, which might be the reason why their results have not a universal meaning, especially in relation to concentrated sectors. That is why, the Polish financial market appears to be interesting in this context. Banking and insurance markets are much more concentrated, close to an oligopoly where a market is shared by a small number of producers or sellers. ${ }^{2}$ Therefore the process of formation of the relationship with customers of the mobile phone market, with only three dominant enterprises proves to be rather peculiar (Mitrega 2006). The study claims that the affective level of the relationship on the mobile phone market seems to be disturbed, which could be attributed to the feeling of pressure of maintaining a relationship with a simultaneous lack of available alternatives of mobile phone service providers.

Restaurants, hotels, and health care are among the service categories most investigated.

A given insurance company, within the European Union, has a dominant market position if its market share amounts to more than 20\%. PZU Życie S.A. and PZU S.A. were the leading insurance companies of 2013, with their share capital adding up to $29,04 \%$ and $36,63 \%$ respectively, whilst PKO was the leader of the banking sector. 


\section{The multidimensionality of complaint management in the context of perceived justice.}

Factors influencing the conflict between the companies and customers are diversified, which could be observed in previous studies, that analyzed the variables influencing the efficiency of conflict management in the context of perceived justice. According to the concept of social exchange people tend to estimate the very idea of justice of exchange in terms of its results, procedures and interactions between parties, which immediately determines further actions (Adams 1965). Therefore it can be stated that the idea of perceived justice explains the relationship between customers and companies, especially in terms of consumers' complaints.

In most of the studies, the three dimensions of justice are investigated (e.g. Maxham, Netemeyer, 2002; Davidow, 2003; Wirtz, Mattila 2004; Homburg, Fürst, 2005; Hocutt, Bowers, Donavan, 2006; Siu, Zhang, Yau, 2013). These include: distributive justice which refers to the perceived outcome, procedural justice which refers to perceived fairness of the policies and procedures used by decision makers in arriving at the outcome of a dispute, and interactional justice which refers to perceived manner in which the customer is treated (Mattila, 2001). However, one may notice that the dimensions of the definitions of justice are highly "capacious". Nevertheless, the specific wording and scaling used for each measure of justice is very limited. Moreover, recent studies analyzed the impact of perceived justice which classified informational justice as an independent variable (Mattila, Cranage, 2005; Mattila, 2006; Ambrose, 2007; Varela-Neira, Vázquez-Casielles, Iglesias, 2010). Informational justice refers to the perceived adequacy and truthfulness of information explaining the causes for unfavorable outcomes (Colquitt, 2001; Mattila, Cranage, 2005). Certain lack of consistency, among some of the categories falling within these dimensions can be observed, e.g. some studies suggest that „apology” is linked to customer's perceptions of distributive justice (e.g. Tax, Brown, Chandrashekaran 1998; McCollKennedy, Sparks 2003), while other show that it is linked to interactional justice (e.g. Hocutt et al., 2006; Mattila, 2001).

It might serve as a proof that the boundaries separating particular dimensions of justice seem vague to the consumers, which constituted the starting point for the author to carry out her own research that aimed at defining the multidimensionality, in terms of conflict management between the company and the consumer, from the perspective of purchasers of financial services in Poland. The results of this study, which was based on the sample of 404 customers, have been analyzed not only according to one's own prior qualitative tests, but also to other studies concerning this subject.

\section{The study}

In this study, a survey method was adopted. A questionnaire was addressed to individual consumers who have made a complaint towards an insurance company or a bank within last two years. Also the non-random sampling was applied. Random sampling was not possible because of the lack of sampling frame referring to people, who made the complaint. The issue of research relates to the negative aspects of the functioning on the market and the participation in research might have been associated with considerable emotional engagement. As a result, it was reasonable to use the snowball technique, using invitations to the questionnaire. Those invitations were placed on social networking sites, discussion forums and websites of 
organizations dealing with consumer issues.

As the survey participants might or might not have any experience concerning customers' complaints, one of the points in the questionnaire allowed the respondents to indicate the status of their experience.

The online survey was carried out from April to September, 2014. Firstly, the pretest was conducted, in order to establish the final version of the questionnaire. The scale was carefully examined by selected academicians, with special regard for wording, structure and content. Their comments were used to modify the scale, in order to guarantee appropriate reliability and validity. Once the questionnaire had been finalized, the online survey was performed.

A total of 957 online responses were received. Of these, 703 respondents with experience of making a complaint were selected. Then, the incomplete and invalid responses were deleted. 374 left from the insurance market and 202 form banking sector. Since there were much more respondents who were insurance companies' customers, the author made the decision to choose randomly 202 respondents form the insurance market. After these adjustments, the final sample consisted of 404 respondents.

It was assumed that the aim of research would be obtained by means of the exploratory factor analysis. Each of the constructs shown in Table 1 was measured with multi-item scales. The scales were developed to measure the following constructs: distributive justice, procedural justice, interpersonal justice and informational justice. All the measurement items were designed to be evaluated on a seven-point Likert scale ranging from "strongly disagree" to "strongly agree". The measurement items for justice constructs were based not only on a literature review, but were also supplemented by the results of exploratory qualitative research conducted in Poland (Berger 2015). Table 1 shows the complete text of the scales used with their corresponding original codes of justice (e.g. PROC2. - second measurement item relating primarily to procedural justice). It was assumed that every scale had to refer to one of four different aspects of conflict management in the context of perceived justice.

Principal component factor analysis with varimax rotation was performed to investigate the multidimensionality of the proposed constructs. The SPSS program was used. The research instrument could be considered valid, as the loading factor was greater than or equal to 0.6 . The cross-loadings occurred $(>0,4)$ and therefore the decision to remove the items was made. Table 1 shows the factors extracted and the associated loadings. Taking into account the factor loadings, there were seven scale items removed from the measurement model since they did not meet the boundary conditions (italics in table 1). Thirteen scales, which were associated with five relatively distinct constructs (in bold in Table 1) remained.

Series of reliability tests were then performed on items loaded on the extracted constructs. All of the Cronbach's Alpha coefficients were above 0.7, which indicated satisfactory internal consistency reliability (Hair et.al. 2006). Therefore, items loaded on each factor with satisfactory reliability were aggregated to create a composite score of a particular construct. 
Table 1: Factor analysis of the dimensions of justice

\begin{tabular}{|c|c|c|c|c|c|}
\hline \multirow{2}{*}{ Constructs* $^{*}$} & & \multicolumn{3}{|c|}{ Factor loadings } & \multirow[b]{2}{*}{5} \\
\hline & 1 & 2 & 3 & 4 & \\
\hline $\begin{array}{l}\text { DISTR1. In solving my problem, the company } \\
\text { gave me exactly what I needed. }\end{array}$ & ,610 & ,320 & ,392 & & \\
\hline $\begin{array}{l}\text { DISTR2. I received an adequate compensation } \\
\text { from the company. }\end{array}$ & ,683 & & & & \\
\hline $\begin{array}{l}\text { DISTR3. The company offered me a couple of } \\
\text { choices to resolve my complaint. }\end{array}$ & ,737 & ,318 & & & \\
\hline $\begin{array}{l}\text { PROC1. The company quickly resolved my } \\
\text { complaint. }\end{array}$ & 692 & ,434 & & & \\
\hline $\begin{array}{l}\text { PROC2. I believe the company had flexible } \\
\text { procedures to handle my complaint. }\end{array}$ & & ,725 & ,489 & ,390 & \\
\hline $\begin{array}{l}\text { PROC3. The personnel showed enough authority } \\
\text { to make decisions regarding my complaint. }\end{array}$ & & & ,629 & ,327 & \\
\hline $\begin{array}{l}\text { PROC4. My complaint was handled from the start } \\
\text { to the end by a single person. }\end{array}$ & & & ,614 & ,332 & \\
\hline $\begin{array}{l}\text { PROC5. During the complaint situation, I could } \\
\text { communicate with the company in a variety of } \\
\text { ways (eg. call-centre, e-mail etc.) }\end{array}$ & & & ,377 & ,730 & \\
\hline $\begin{array}{l}\text { PROC6. I was informed about the status of the } \\
\text { complaint I made. }\end{array}$ & & & & ,738 & \\
\hline $\begin{array}{l}\text { INTER1. The employees treated me in a polite } \\
\text { manner. }\end{array}$ & & ,603 & ,480 & ,399 & 475 \\
\hline $\begin{array}{l}\text { INTER2. The employees were trying to } \\
\text { understand my problem. }\end{array}$ & & ,856 & & & \\
\hline $\begin{array}{l}\text { INTER3. The employees put the proper effort into } \\
\text { resolving my problem. }\end{array}$ & &, 606 & & ,472 & \\
\hline INTER4. The employees were honest with me. & &, 724 & & & ,316 \\
\hline $\begin{array}{l}\text { INTER5. The company apologized for what has } \\
\text { happened. }\end{array}$ & & 481 & 623 & & \\
\hline $\begin{array}{l}\text { INTER6. The employees were } \\
\text { competent/professional. }\end{array}$ & & ,718 & ,351 & ,490 & \\
\hline $\begin{array}{l}\text { INTER7. The employees had adequate knowledge } \\
\text { of the products and procedures within the } \\
\text { company. }\end{array}$ & & ,709 & ,314 & & ,303 \\
\hline $\begin{array}{l}\text { INTER8. The employees listened carefully to what } \\
\text { I had to say. }\end{array}$ & & ,812 & & ,353 & \\
\hline $\begin{array}{l}\text { INFOR1. The explanations regarding the problem } \\
\text { were reasonable. }\end{array}$ & & & & & ,750 \\
\hline $\begin{array}{l}\text { INFOR2. The procedures, under which the decision } \\
\text { about my complaint was made, were explained by the } \\
\text { company thoroughly. }\end{array}$ & & 671 & ,432 & ,474 & ,371 \\
\hline $\begin{array}{l}\text { INFOR3. The language in which the company } \\
\text { explained its actions and decisions was } \\
\text { understandable (eg. lack of complicated terms). }\end{array}$ & & & & & 861 \\
\hline
\end{tabular}

Source: own collaboration 


\section{The dimensions of complaint handling evaluation - customers' perspective}

On the basis of the study five dimensions of justice of customer's complaint on the financial market have been distinguished.

The first factor referred to the outcomes of complaint process and was clearly labeled as distributive justice. The following components have been enumerated: providing the customer with the adequate solution (DIST1), appropriate compensation (DIST2) and offering alternative possibilities of solving of a complaint (DIST3). It is worth mentioning that the interviews performed among the representatives of the banking and insurance sectors (that have been done for the author's qualitative tests preceding the survey), have shown that customers are unable to influence the company's decisions regarding the complaints, and that in the end they are only informed about the company's decision.

Next factor uncovered only two dimension of procedural justice: single-person complaint handling (PROC3) and empowerment (PROC4). Regardless of the fact that the aforementioned variables have not been taken into consideration in former studies, they fit into the procedural level of justice of complaint resolving. The fact that customers' complaints are being serviced in a one-person manner seems to have considerable significance. First of all, during last 10 years the process of customer servicing have been done by means of a telephone. In the case of outsourced projects major problems included: a very high level of staff rotation, and the fact that quite frequently the employees seemed to be misassigned to a given project. It is also often the case that the customer service adviser lack the very basic knowledge of financial services, which directly deteriorates the evaluation of the whole process by the customers. Staff authorization also needs to be taken into account. Author's prior study (Berger 2015) has shown that the lack of authorization in decision-making on the side of the persons involved in the complaint processing was a source of irritation. Customers claimed that it caused unnecessary prolongation of the whole complaint process.

The third factor extracted was named by the author as communication justice, since it consists of scales clearly connected with communication issues: "the possibility of communication with the company in a variety of ways" (PROC5) and "being informed about the status of the complaint" (PROC6). Qualitative studies also indicated the significance of this issue. In interviews carried out among bank and insurance customers some sources of customers' objections became apparent. Firstly, the fact that the employees have not been updated as to the current situation of the customer's complaint, secondly they were unwilling to discuss the points of disagreement, and thirdly generally the channels of communication were maladapted.

Five factors were extracted for interpersonal justice. They refer to empathy (INTER2), honesty (INTER4), product and procedures knowledge (INTER7) and active listening (INTER8). The combination of the acceptance of the customer's perspective and the understanding of his/her problem enables the dialogue between the two parties without the escalation of the problem. Standing in the customer's shoes might play a great role, since their situation is less favorable, as they do not possess the knowledge of legal matters concerning complaints, nor do they know the market to such an extend that would allow them to cope with the issue on their own. Customers expect that the people dealing with complaints be honest and empathic, which is quite understandable, especially if we are aware of the role that customer's trust has in the 
context of complaints, what has been confirmed by studies carried out by ChęcińskaZaucha (2013). As to customers expectations concerning the procedural as well as product knowledge of first line workers, it can be said that it stems from the complexity of financial services that frequently serves as a source of troubles for the customers. The study also emphasized the importance of the ability of active listening, which serves as a confirmation for studies carried out on foreign markets (Gruber 2011).

Finally, two factors were extracted for informational justice. One was related to statements measuring reasonable explanation (INFOR1), while the other was concerned with the understandable language (INFOR3).

\section{CONCLUSION}

Recent studies carried out in economically developed, western countries suggested the distinction of three dimensions of justice, nonetheless other studies signalized that this approach should be abandoned. This study was based on the thesis that the multidimensionality of conflict management depends not only on specific characteristics of a given sector, but also on the qualities of a given national culture. The study includes the results of a survey made among those bank and insurance customers in Poland, who have longed a complaint.

As the study showed, five dimensions of just complaint management could be distinguished. First dimension relates to the distributive dimension, which according to the meta analysis carried out by Orshinger et al. (2010) is of utmost importance in the situation of a customer complaint. It needs to be emphasized that customers value a certain amount of freedom that allows them to choose whether they accept or reject the offer proposed by the company. Matilla (2001) has already proved a positive outcome of this approach, where it has been suggested that the company's image could benefit greatly from providing their customers with freedom of choice, rather than providing them only with standard solutions.

Studies shown that the evaluation of the procedures used on Polish financial market can be reduced to two variables. Customer's expectations towards one-person complaint management provides us with interesting insights, which confirms the outcomes of studies carried out by De Vyre (1994, p. 64), in which it has been stated that $70 \%$ of customers are satisfied if their issue is being processed by one specific person within the company. If customers were to discuss their issue with two persons then the satisfaction rate dropped to $61 \%$, the more people were involved in the process the lower the satisfaction rate became. Assigning only one particular individual to a given complaint requires giving them certain amount of authorization and autonomy in decision-making. Employees' authorization is a variable that has not been taken into consideration in the measuring scale of just complaint resolving, even though its significance in the context of resolving conflicts has been proven (Boshoff, Leong 1998). Hart, Heskett and Sasser (1990) also stressed the role of authorisation of first line employees, since they are the first to identify the issue. It also impacts further course of action in the process of problem solving. First line employees possess the knowledge of customers' expectations concerning the service as well as their needs once they encounter certain difficulties (Dewar 1993). Probably, the need of this variables can be explained by the fact, that customers on the insurance market expect that the insurance agent will handle their complaint or speak on behalf of an insurance company, because he is usually the one who knows the customer personally and stay in touch with the customer. 
Further observations of this study enabled to distinguish a new dimension for customers that report a complaint, that is the communication with the customer that seems to have gained new meaning on Polish financial market.

Presented results led to an ascertainment that the relation between the financial company's staff and the customer is of considerate importance during the process of complaint management (Gayathri, Vinaya, Lakshmisha 2005, Gera 2011). Also the following qualities appeared to be important: honesty, empathy, knowledge and the ability of active listening. It has already been proven that empathic skills have a positive effect on customer's behaviour on the polish financial market. Additional results of studies carried out in Poland suggest that one of the greatest obstacles in the relationship with the customer was the lack of empathy on the side of the employee (Nowotarska-Romaniak 2005). As far as the knowledge of those who service the complaint is considered, customers frequently look for guidance and advice, that is why it is so crucial that the employees have the knowledge required for solving the problems reported by the customers. Previous studies done on financial market confirmed that staffs' knowledge plays a vital role in the formation of the relationship between the insurance company and their customer (Gayathri, Vinaya, Lakshmisha 2010). Further studies emphasized the role of active listening, which can also be find in publications concerning sales management and personal selling (Clopton, Stoddard, Clay 2001). Clapton, Stoddard and Clay's (2001) experiment has proven that the person lodging a complaint to a seller who is willing to listen to $\mathrm{him} / \mathrm{her}$, and who possesses a good knowledge of the product s/he sells, is more willing to recommend that shop to his/her friends and will also visit that shop him/herself in the future. It has also been observed that not only is the urge of reporting the complaint to the management lesser, but also that the customer does not feel guilty about making the complaint.

Another important aspect was the confirmation of the validity of the acceptance of the four dimensions of justice in complaint management, which has also been presented in Lee's and Park's (2011) study concerning customers satisfaction. The study also mentioned that the lack of clarity and honesty in information giving is the main reason for lowering customer's satisfaction. Pashaie Fatemi and Ahmadi (2013) and Witkowska (2008) have also stressed the need of providing the customers with unambigious information and proper explanations on the financial market.

Aforementioned conclusions may be further supplemented by the cultural perspective. According to Hofstede's (2011) classification of cultural dimensions, Polish society could be characterised by a high level of uncertainty evasion, which would explain the significance of informational and communicative dimensions of complaint management. Reimann Lunemann and Chase (2008) and Patterson, Cowley and Prasongsukarn (2006) have proved that in cultures with high levels of uncertainty avoidance the need of structured relations and immediate actions in equivocal situations is widely emphasized. Other studies concerning complaint management have also shown that in national cultures of highly individualized countries the interactional level of justice in complaint management is of great importance (Mattila, Patterson 2004). Even though collectivism is slightly dominant within the Polish society (especially among family members and friends), the situation differs among young people who show certain amount of individualism (Hrynkiewicz 2004), which has been shown by the author of the study.

Taking into account the conclusions presented in this study, following cautious managerial inferences might be presented. Insurance companies should have a 
transparent policy of compensation providing as well as a set of alternative methods of settling customers' arguments in an amicable manner. It would also seem reasonable to engage the customers in the process of problem solving. Furthermore, the companies should pay more attention to the quality of communication with the customer who makes a complaint. Last but not least, companies should select their employees with great amount of consideration, since from the customer's perspective they represent the company.

\section{Acknowledgement}

Project financed with the resources of National Science Centre on a basis of decision no DEC-2012/07/N/HS4/00269.

\section{References}

ADAMS, J.S. (1965). Inequity in social exchange. Advance in Experimental Social Psychology. 1965, Vol. 2., 267-299.

BERGER, M. (2015). The determinants of successful conflict management on the insurance market in Poland, from the perspective of the explorative research. Advances In Business-Related Scientific Research Journal. 2015, Vol. 15, No. 1, p. 31-42.

BOSHOFF, Ch. and LEONG, J. (1998). Empowerment, attribution and apologising as dimensions of service recovery An experimental study. International Journal of Service Industry Management. 1998, Vol. 9, p. 24-47.

CHĘCIŃSKA-ZAUCHA, A. (2013). Marketing relacji na rynku ubezpieczeń majątkowych w Polsce. PhD dissertation. Katowice: Wydawnictwo UE Katowice. 2013.

CLOPTON, S.W.; STODDARD, J.E. and CLAY, J.W. (2001). Salesperson characteristics affecting consumer complaint responses. Journal of Consumer Behaviour. 2001, Vol. 1, No. 2, p. 124-139.

De VYRE, C. (1994). Good Service is Good Business, Australia: Prentice Hall. 1994.

DEWAR, R.D. (1993). Customer relations under fire. Executive Excellence. 1993, Vol. 10, No. 8, p. 1516.

GAYATHRI, H.; VINAYA, M.C. and LAKSHMISHA, K. (2005). A pilot study on the service quality of insurance companies. Journal of Services Research. 2005, Vol. 5, No. 2, p. 123-138.

GERA, R. (2011). Modelling the service antecedents of favourable and unfavourable behaviour intentions in life insurance services in India: An SEM study. International Journal of Quality and Service Sciences. 2011, Vol. 3, No. 2, p. 225-242.

GRUBER, T. (2011). I want to believe they really care. How complaining customers want to be treated by frontline employees. Journal of Service Management. 2011, Vol. 22 No. 1., p. $85-110$.

HAIR, J.F.; BLACK, C.; BABIN, B.J.; ANDERSON, R.E. and TATHAM, R.L. (2006). Multivariate Data Analysis, Pearson International Edition, Prentice Hall: New Jersey. 2006.

HART, CH.W.L.; HESKETT, J.L. and W.E. SASSER Jr. (1990). The Profitable Art of Service Recovery. Harvard Business Review. 1990, Vol. 68, No. 7/8, p. 148-56.

HOFSTEDE, G. (2011). Kultury i organizacje. Zaprogramowanie umysłu. Warszawa: Wydawnictwo PWE. 2011.

HRYNKIEWICZ, J. (2004). Political and cultural context of economic development (Original title: Polityczny i kulturowy kontekst rozwoju gospodarczego). Warszawa: Wydawnictwo naukowe Scholar. 2004.

KAUR, M.; NEGI, A. (2010) A Study of Customer Satisfaction with Life Insurance In Chandigarh Tricity. Paradigm. 2010, Vol. 14 No. 2., p. 187-196.

LEE, E-J. and PARK, J-K. (2010). Service failures in online double deviation scenarios: justice theory 
approach. Managing Service Quality. 2010, Vol. 20, No. 1, p. 46-69.

MATTILA, A.S. and PATTERSON, P.G. (2004). The impact of culture on consumers' perceptions of service recovery efforts. Journal of Retailing. 2004, Vol. 80, p. 196-206.

MITREGA, M. (2006). Building strong relationships between services' providers and consumers: Evidence from Poland. Transformations in Business \& Economics. 2006, No. 5 (2), p. 148-162.

NEFAT, A.; BENAZIC, D. and ALERIC, D. (2012). Antecedents and outcomes of service recovery satisfaction in telecommunications in Croatia along with the role of image and perceived switching costs. Ekonomska Istrazivanja. 2012, Vol. 25, No. 4., p. 37-54.

NOWOTARSKA-ROMANIAK, B. (2005). Marketing orientation of Polish insurance companies (Original title: Marketingowa orientacja firm ubezpieczeniowych w Polsce), Katowice: Wydaw. UE Katowice. 2005.

ORSINGHER, CH.; VALENTINI, S. and DE ANGELIS, M. (2010). A meta-analysis of satisfaction with complaint handling in services. Journal of the Academy of Marketing Science. 2010, Vol. 38, No. 2, p. 169-186.

PASHAIE, R.; FATEMI, A. and AHMADI, F. (2013). Exploration of SERVQUAL scale in the Insurance services in Kurdistan insurance institute. Interdisciplinary Journal Of Contemporary Research in Business. 2013, Vol. 5, No 5, p. 172-187.

PATTERSON, P.G.; COWLEY, E. and PRASONGSUKARN, K. (2006). Service failure recovery: the moderating impact of individual-level, cultural value orientation on perceptions of justice. International Journal of Research in Marketing. 2006, Vol. 23, No. 3.

REIMANN, M., LUNEMANN, U.F. and CHASE, R.B. (2008). Uncertainty avoidance as a moderator of the relationship between perceived service quality, and customer satisfaction. Journal of Services Research. 2008, Vol. 1, No. 1, p. 68-76.

SIDDIQUI, M.H. and SHARMA, T.G. (2010). Analyzing customer satisfaction with service quality in life insurance services. Journal of Targeting, Measurement and Analysis for Marketing. 2010, Vol. 18, No. 3/4, p. 221-238.

WITKOWSKA, J. (2008). Distributive channels of insurance services (Original title: Kanały dystrybucji usług ubezpieczeniowych). Toruń: Dom Organizatora. 2008.

WYGNAŃSKI, J.J. and HERBST, J. (2010). Operations for increasing social capital, as part of the strategy of country development 2007-2015 (Original title: Działania na rzecz zwiększenia kapitału społecznego - w ramach aktualizacji strategii rozwoju kraju 2007-2015), Warsaw. 2010. 